\title{
Meetings
} Calendar

\section{Presenting upcoming meetings and calls for papers}

Symposia Proposals and Abstract Submissions: For TMS-sponsored meetings, symposia proposals and abstracts must be submitted through ProgramMaster, the on-line TMS conference and proceedings management system. The system can be accessed at www.tms.org. Using the Meetings \& Events pulldown menu, select the Upcoming TMS Meeting for which you wish to submit a symposia proposal or an abstract, and follow the on-line instructions. The society especially encourages the submission of "hot-topic" symposia or special-session proposals on timely or developing subjects. To advance an idea, use the symposium creation form in ProgramMaster. Additional information can be acquired from the TMS Technical Support Services Department, 184 Thorn Hill Road, Warrendale, PA 15086; (724) 776-9000, ext. 275; fax (724) 776-3770.

\section{TMS-Sponsored Events}

\section{TMS2013}

March 3-7, 2013

San Antonio, Texas

The TMS 2013 Annual Meeting \& Exhibition brings together more than 3,800 professionals in the materials field for an outstanding exchange of technical knowledge. TMS2013 will also include the symposium REWAS 2013: Enabling Metal Resource Sustainability, which will provide a platform for fields to facilitate the transition to a more sustainable industry and society. Contact: Meeting Services, TMS, 184 Thorn Hill Road, Warrendale, PA 15086; (724) 776-9000, ext. 243; fax: (724) 776-3770; e-mail: mtgserv@tms.org;www .tms.org/meetings/annual-13/AM13home .aspx.

\section{ICME 2013}

July 7-10, 2013

Salt Lake City, Utah

Integrated computational materials engineering (ICME) has received international attention due to its great potential to shorten product and process development time, while lowering cost and improving outcome. ICME 2013 will examine topics as foundational engineering problems addressed by an ICME approach; individual computational components of an ICME program; challenges in integrating models to achieve ICME; experimental programs and techniques that support ICME efforts; data management issues; ICME in engineering education; and others. Contact: Meeting Services, TMS, 184 Thorn Hill Road, Warrendale, PA 15086; (724) 7769000, ext. 243; e-mail mtgserv@tms.org; www.tms.org/meetings/2013/ICME2013 /home.aspx.

\section{PRICM-8}

August 4-9, 2013

Waikoloa, Hawaii

Held every three years, this Pacific Rim International Conference on Advanced Materials and Processing - the $8^{\text {th }}$ in the series - is being organized this year by TMS. The conference is jointly sponsored by CSM, JIM, MA, and KIM and rotates among these sponsoring organizations. PRICM-8 will include presentations on topics such as advanced high-temperature structural materials; advanced steels and processing; bulk metallic glasses and nanomaterials; thin films and surface engineering; materials for energy; materials for the environment; rare earth, electronic and magnetic materials; and many others. Contact: Meeting Services, TMS, 184 Thorn Hill Road, Warrendale, PA 15086; (724) 776-9000, ext. 243; fax: (724) 776-3770; e-mail: mtgserv@tms.org; www.tms .org/meetings/specialty/pricm8/home .aspx.

\section{MS\&T'13}

October 27-31, 2013

Montreal, Quebec, Canada

The MS\&T (Materials Science \& Technology) partnership of four leading materials societies-ACerS, AIST, ASM, and TMS-brings together scientists, engineers, students, policy makers, suppliers and more to discuss current research and technical applications, and to shape the future of materials science and technology. Since corrosion remains a relevant topic to materials, NACE International will again co-sponsor MS\&T. Whether just starting a career in materials science or seasoned professional, MS\&T offers an unmatched opportunity to network and learn. Contact: Meeting Services,TMS, 184 Thorn Hill Road, Warrendale, PA 15086 USA; (724) 776-9000, ext. 243; fax (724) 776-3770; mailto:mtgserv@tms.org;www.matscitech .org/about/future-meetings.

\section{TMS Co-sponsored Events}

Offshore Technology Conference 2013: May 6-9, 2013; Houston, Texas; www.otcnet.org/2013/

Magnesium Workshop Madrid 2013: May 21-24, 2013, Madrid, Spain; www.tms.org/meetings/2013/MagnesiumWorkshopMadrid/.

\section{General Meetings}

142nd SME Annual Meeting and Exhibit: February 24-27, 2013; Denver, Colorado; www.smenet.org/meetings.

PDAC 2012 International Convention, Trade Show \& Investors Exchange: March 3-6, 2013; Toronto, Canada; www.pdac.ca/pdac/conv/index.aspx.

3rd Annual Compound Semiconductor International Conference: March 4-5, 2013; www.cs-international.net/.

Aeromat Conference and Exposition: April 2-6, 2013; Bellvue, Washington; www.cs-international.net.

IMS Quantitative Metallography: April 3-5, 2013; San Antonio, Texas; www.asminternational.org/content/Events/quantmet/index.jsp.

Fourth International Conference on Accelerated Carbonation for Environmental and Materials Engineering (ACEME13): April 10-12, 2013; Leuven, Belgium; cit.kuleuven.be/aceme13/.

IEEE SSCI 2013 - 2013 IEEE Symposium Series on Computational Intelligence: April 15-19, 2013; Singapore; ieee-ssci.org/.

IMCET 2013 - 23rd International Mining Congress and Exhibition of Turkey: April 16-19, 2013; Antalya, Turkey; www.imcet.org.tr/.

CIM 2013 Convention: May 5-8, 2013; Toronto, Ontario, Canada; web.cim.org/toronto2013beta/.

5th International Conference on Recyrstallization and Grain Growth: May 5-10, 2013; Sydney, Australia; www.rex-gg2013.org/.

Sustainability through Resource Conservation and Recycling '13: May 6-8, 2013; Falmouth, Cornwall, U.K.; www.min-eng-com/srcr13/. 